Works of the Faculty of Forestry

University of Sarajevo

No. 2, 2018 (54-64)

UDK 639.124(497.11)

\title{
VIABILITY OF THE POPULATIONS OF PERDIX PERDIX L. AT MT. FRUŠKA GORA AND SREMSKA RAČA, REPUBLIC OF SERBIA
}

\section{Održivost populacija Perdix perdix L. na Fruškoj Gori i u Sremskoj Rači, Republika Srbija}

Vejzagić Selma ${ }^{1}$

\begin{abstract}
Perdix perdix L. (also known as the Grey partridge, English partridge, and Hungarian partridge) populations have been declining for years in natural habitats and areas in which this species of wildlife has been introduced. Hunting grounds at the base of $M t$. Fruška Gora and Sremska Rača in the Republic of Serbia provide excellent conditions for its breeding. In addition to the data from hunting records about population quantity of the $P$. perdix, a direct monitoring allows a relevant inside to its' quantity in hunting associations' hunting grounds. The decline of population quantity is mostly the result of the use of chemicals for protection of agricultural crops (10\%), destruction of nests and bird eggs (12.5\%), and the failure to implement failure wildlife-protection measures, by forbidding the hunt of $P$. perdix $(5 \%)$, and the use of poisons on agricultural crops, such as the forbidden poison Furadan (5\%). Although no significant results have been obtained on the impact of predators and abandoned animals on the reduction of $P$. perdix population, there is a justified concern by hunting associations' in terms of finding ecologically and biologically viable solutions for impact on predators on feathered game, and especially abandoned dogs. The results of the study were obtained by the method of directly determining the number of $P$. perdix in the crop fields, in the hunting grounds of L.D. "Fazan Mala Remeta", L.D. "Fazan" Jazak, L.D. "Stejanovci" Stejanovci, L.D. "Zec" Vrdnik and L.D. "Srndać" Sremska Rača. The obtained results directly the need to introduce the principle of integral protection of $P$. perdix, which implies control over the implementation of measures for the protection of agricultural crops and the implementation of $P$. perdix protection measures during the organization of hunting on other game species in hunting grounds.
\end{abstract}

Key words: P. perdix L., population, hunting ground, agricultural crops, Fruška Gora, Sremska Rača, poison

\section{INTRODUCTION - Uvod}

According to OPHOVEN, (2010), the grey partridge comes from family Perdicinae. This species can be $29-31 \mathrm{~cm}$ wide, and $45-48 \mathrm{~cm}$ tall, reaching the total mass of 350-450 g (OPHOVEN, 2010). March and April are mating months, and incubation lasts 24-26 days, after females give 10-25 chicks (OPHOVEN, 2010). According to OPHOVEN (2010), females ley eggs at the edges of cereal winter fields.

\footnotetext{
${ }^{1}$ MA Forestry, Faculty of Forestry, University of Sarajevo
} 
Different impacts from the nature, but also human activity, make this species very sensitive, so its' existance depends on ecological management in wildlife ecosystems. According to MIKSCH et al., (1998-2004), the grey partridge is very sensitive to a hair worm, who leaves eggs in birds' hair, making it host to a parasites. MIKSCH et al., (19982004) give Echinococcus multilocularis as an example of parasite attacking the grey partridge very often, producing more than 100 eggs in its' hair. In capital originaly named „Die letzen Gefahren im deutschen Wald“, MIKSCH et al., (1998-2004) describe E. multilocularis as the greatest parasite of all wildlife in german forests (german name for the worm is Kleiner Fuchsbandwurm). The grey partridge is also affected by $\mathrm{HN}$ virus, birds' plague and birds' cholera (OPHOVEN, 2010), so not only by parasites, but also by all natural hairy predators, scavenger birds (hawk, buzzard etc.), wild cat, bisam rat, eagle etc.

Since a female of the investigated species is laying eggs in the ground of crop field, it is important to know the influence of herbicide and pesticides on this species. According to OPHOVEN, (2010), the sooner we understand the use of herbicides and pesticides in the fields' protection, that will provide more chances for the survival of grey partridge and exceed the opportunity to manage this species as hunting. Pesticides and herbicides are retained in the soil, and in the larvae and insects that birds eat. In the Report of the GREENPEACE (May 2015), KÖHLER and TRIEBSKORN (2013) wrote that increasing the number of pesticide and herbicide impact' studies on wildlife had exponentially increased over the last 30 years.

Republic of Serbia is one of the leading producers of food in its' region. It is known by its' large cereal fields but also very diverse wildlife inhabited in crops. Different chemicals used in agriculture make grey partridge sensitive and even vunerable species, so the need of protection of this species is greater than ever. The conducted study needs to identify the problems that cause disappearing of this species from fields and to give possible solutions for resolving the existing problem of decreasing the number of birds in Republic of Serbia, so this study needs to identify the real problems of disappearing partridges.

\section{MATERIAL AND METHODS - Materijal i metode}

\section{Hunt science research today - Savremena istraživanja iz Lovstva}

Wildlife management is part of modern Forestry Science - field of Integral protection of forests, wildlife and bioecosystems, that has got very hard task in modern era - to keep the balance between the bioecological characteristics and demand of living organisms and increasing demands and needs of human population on Earth, for its' survival. Beeing a hunt researcher in modern era is a specific and hard work, according all the incoming demands from different stake-holders, interested in protecting the nature resources.

\section{Material of research - Materijal istraživanja}

In this study, the material of research are live and dead examples of grey partridges, their nests, eggs and chicks, located in five different hunting grounds. 
Vlabılıty of the populatıons of Perdlx perdıx L. at Mt. Fruška Gora and Sremska Rača, Republic of Serbia

Period of research and specifics of research area - Vrijeme istraživanja $i$ specifičnosti istraživanog područja

The evidenting the number of grey partridges was conducted in certain time period, 2016 ${ }^{\text {th }}-2018^{\text {th }}$ year. The research area include hunting ground of five hunting associations: L.D. "Fazan Mala Remeta", L.D. "Fazan" Jazak, L.D. "Stejanovci" Stejanovci, L.D. "Zec" Vrdnik and L.D. "Srndać" Sremska Rača, that manage 2200 ha of crops, inhabited with different hunting wildlife. The climate and vegetation present in theese five hunting grounds has positive impact on grey partridge' reproduction, growth and living. The whole area is rich with natural food and plenty of insects eaten by chicks of partridges. All the crops in hunting grounds present the hunt productive surfaces, except 100 ha of crops in boundaries of L.D. "Fazan Mala Remeta", that is usurpated by the plant nursery in near place.

The need for using method of counting total number of birds - Potreba za primjenom metode potpunog prebrojavanja ptica

The counting of all the birds in the hunting grounds is needed in case of missing the relevant data in evidences of hunting associations, but also in case of conducting the serious research, that is related to identifying the precise number of birds affected by certain factor. Precise number of birds is important indicator of biological and ecologycal problems affecting wildlife in certain hunting ground.

Goals needed to be reached by using method of total counting of birds - Ciljevi koje treba ostvariti primjena metode potpunog prebrojavanja ptica

In the study, birds and bird flocks were counted directly in hunting grounds in $2018^{\text {th }}$, and data about quantity of the partridges in period $2016^{\text {th }}-2017^{\text {th }}$ were taken from evidences of hunting associations, in aim to comparise results of previous counting of birds with new results, that helped to answer main aims of the research:

1. Explore the number of dead birds in hunting grounds caused by different impacts.

2. Find the relative percentage (\%) of dead birds in hunting grounds caused by different impacts (Total number of observed birds $N=400$, Absolute percentage $=100 \%)$.

3. Identify the main problem affecting birds population in different hunting grounds, shown by relative percentage of dead birds.

Parameters that needs to be measured to reached the goals of using method of total counting - Parametri koji će se mjeriti kako bi se ostvarili ciljevi primjene metode potpunog prebrojavanja

There are four measuring parameters in this study: 1) Use of chemicals in protection of agricultural crops; 2) Illegal hunt of partridges; 3) Destruction of nests and bird eggs and 4) Use of poisons in protection of agricultural crops. 


\section{RESULTS - Rezultati}

In this study, we got four main results of research, that will help understanding the main problems affecting grey partridge' populations in Republic of Serbia, giving directions how to improve management of this species in hunting grounds.

First result of the study is given in Table 1 .

Table 1. Number state of P. perdix L. populations of grey partridge (Perdix perdix L.) at Mt. Fruška Gora and Sremska Rača for 3-year period (2016-2018)

Tabela 1. Brojno stanje populacija jarebice poljske (Perdix perdix L.) na Fruškoj Gori i u Sremskoj Rači za trogodišnji vremenski period (2016-2018)

\begin{tabular}{|c|c|c|c|}
\hline Hunting ground & $\begin{array}{c}\text { Number of birds in } \\
2016\end{array}$ & $\begin{array}{l}\text { Number of birds in } \\
2017\end{array}$ & $\begin{array}{c}\text { Number of birds in } \\
2018\end{array}$ \\
\hline $\begin{array}{l}\text { L.D. "Fazan" Mala } \\
\text { Remeta }\end{array}$ & $\begin{array}{c}1 \text { flock of } 10 \text { pairs of } \\
\text { birds }=20 \text { birds }\end{array}$ & $\begin{array}{l}2 \text { flocks of } 10 \text { pairs } \\
\text { of birds }=40 \text { birds }\end{array}$ & $\begin{array}{l}2 \text { flocks of } 12 \text { pairs } \\
\text { of birds }=48 \text { birds }\end{array}$ \\
\hline L.D. "Fazan" Jazak & $\begin{array}{l}1 \text { flock of } 10 \text { pairs of } \\
\text { birds }=20 \text { birds }\end{array}$ & $\begin{array}{c}1 \text { flock of } 10 \text { pairs of } \\
\text { birds }=20 \text { birds }\end{array}$ & $\begin{array}{l}2 \text { flocks of } 13 \text { pairs } \\
\text { of birds }=52 \text { birds }\end{array}$ \\
\hline $\begin{array}{l}\text { L.D. "Stejanovci" } \\
\text { Stejanovci }\end{array}$ & $\begin{array}{l}2 \text { flocks of } 6 \text { pairs of } \\
\text { birds }=24 \text { birds }\end{array}$ & $\begin{array}{c}3 \text { flocks of } 6 \text { pairs of } \\
\text { birds }=36 \text { birds }\end{array}$ & $\begin{array}{l}6 \text { flocks of } 6 \text { pairs } \\
\text { of birds }=72 \text { birds }\end{array}$ \\
\hline L.D. "Zec" Vrdnik & $\begin{array}{l}2 \text { flocks of } 6 \text { pairs of } \\
\text { birds }=24 \text { birds }\end{array}$ & $\begin{array}{l}3 \text { flocks of } 6 \text { pairs of } \\
\text { birds }=36 \text { birds }\end{array}$ & $\begin{array}{l}3 \text { flocks of } 6 \text { pairs } \\
\text { of birds }=36 \text { birds }\end{array}$ \\
\hline $\begin{array}{l}\text { L.D. "Srndać" } \\
\text { Sremska Rača }\end{array}$ & $\begin{array}{l}8 \text { flocks of } 10 \text { pairs } \\
\text { of birds }=160 \text { birds }\end{array}$ & $\begin{array}{l}9 \text { flocks of } 12 \text { pairs } \\
\text { of birds }=216 \text { birds }\end{array}$ & $\begin{array}{l}12 \text { flocks of } 8 \text { pairs } \\
\text { of birds }=192 \text { birds }\end{array}$ \\
\hline Total & 248 & 348 & 400 \\
\hline
\end{tabular}
Graph 1.

The number of dead birds in hunting grounds, caused by different impacts, is given in 
Vlabllty of the populatıons of Perdıx perdıx L. at Mt. Fruška Gora and Sremska Rača, Republic of Serbia

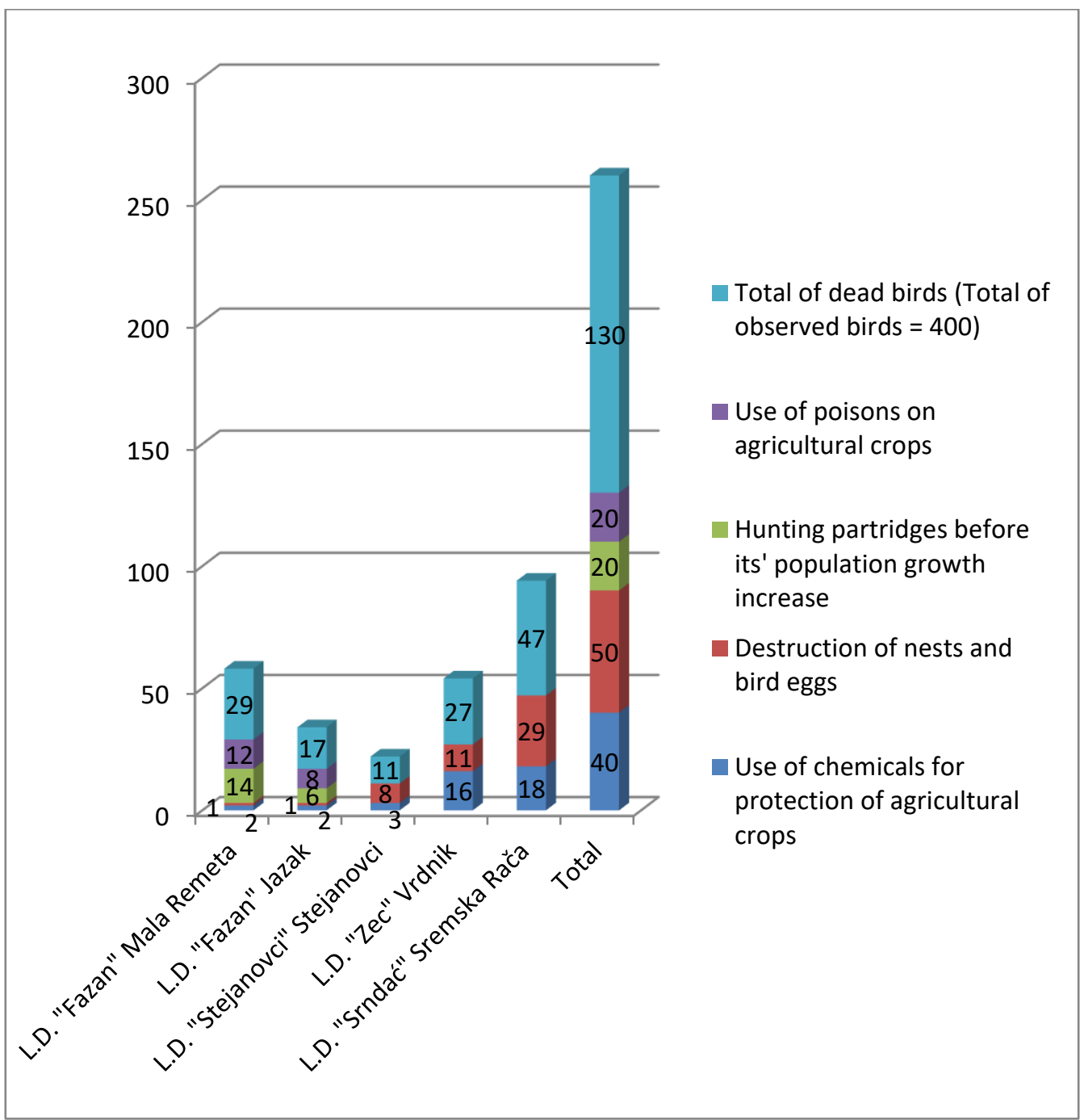

Graph 1. Number of dead birds of $P$. perdix L. affected by different impacts, evidented in explored hunting grounds

Grafik 1. Broj stradalih ptica P. perdix L. uslijed različitih faktora, evidentiran u istraženim lovištima

Relative percentage (\%) of dead birds in hunting grounds caused by different impacts is given in Table 2 . 
Table 2. Relative percentage (\%) of dead birds of $P$. perdix L. in hunting grounds, affected by different impacts (Total number of observed birds $=400$, Absolute percentage $=100 \%$ )

Tabela 2. Relativno procentualno učešće stradalih ptica P. perdix L. u lovištima, uslijed uticaja različih faktora (Ukupan broj posmatranih ptica $=400$, Apsolutni procenat posmatranih ptica $=100 \%$ )

\begin{tabular}{|c|c|c|c|c|c|c|}
\hline Different impacts on birds & 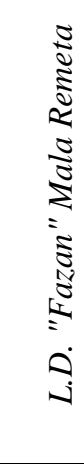 & 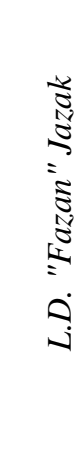 & 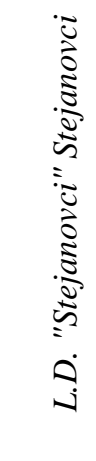 & 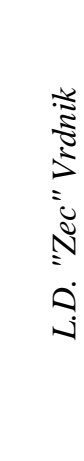 & 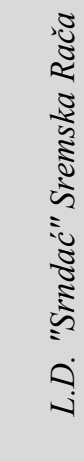 & $\frac{\sqrt{5}}{0}$ \\
\hline $\begin{array}{c}\text { Use of chemicals for protection of } \\
\text { agricultural crops }\end{array}$ & 0,5 & 0,5 & 0,75 & 4 & 4,5 & 10,25 \\
\hline Destruction of nests and bird eggs & 0,25 & 0,25 & 2 & 2,75 & 7,25 & 12,5 \\
\hline $\begin{array}{l}\text { Hunting partridges before its' population } \\
\text { growth increase }\end{array}$ & 3,5 & 1,5 & 0 & 0 & 0 & 5 \\
\hline Use of poison on agricultural crops & 3 & 2 & 0 & 0 & 0 & 5 \\
\hline
\end{tabular}

The main problem affecting birds population in different hunting grounds, shown by relative percentage of dead birds, is given in Graph 2.

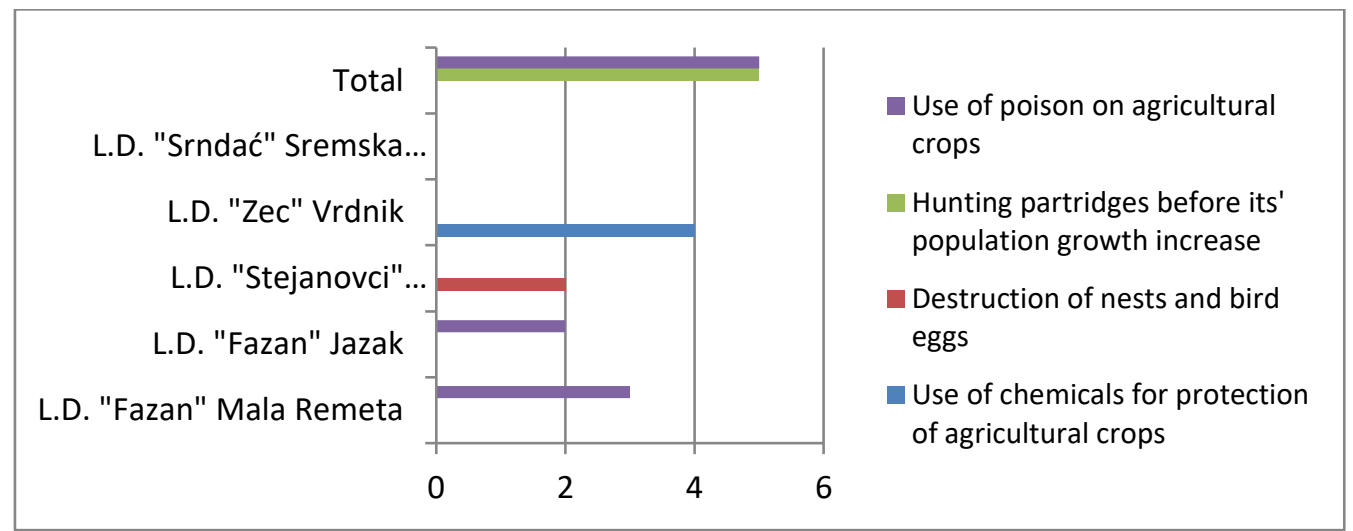

Graph 2. The main problem affecting birds populations of $P$. perdix L. in different hunting grounds at Mt. Fruška Gora, shown by relative percentage of dead birds

Grafik 2. Najvažniji problem koji pogađa populacije ptica vrste P. perdix L. u različitim lovištima na Fruškoj Gori, prikazan relativnim procentualnim učešćem stradalih ptica 


\section{DISCUSSION AND CONCLUSIONS - Diskusija i zaključci}

The obtained results directly indicate to a need of introducing the principle of integral protection of $P$. perdix, which implies control over the implementation of: 1) Protection measures of agricultural crops and 2) Protection measures of $P$. perdix, during the organization of hunting on other game species in hunting grounds.

Populations of grey partridges have been increasing in last three years (from 248 in 2016, to 400 in 2018), thanks to changing the chemicals used in agriculture. According to reports of presidents of hunting associations, in the past there had been used different poisoning chemicals for protecting the fields of vegetables and cerals from birds, rats, insects and also different game species in that area. Inovations in agriculture and buying new chemicals for plant protection brought a new principle of growing food and cereals, but there are still disadvantages in new way of agriculturing crops. The fields today are becoming wider, without natural borders formed by grasses and bushes, as the secure protection for grey partridges from predators, but also causing number of nests deacresed, because birds still have not gotten used on new conditions for mating and reproducing on wider crops (partridges gotten used on making nests on the edges of the smaller fields). In hunding area in Mala Remeta, there is a slower rate of increasing the grey partridges.

According to the report of the president of hunting association, there has been evidented poach, so the partridges are illegaly hunted even in periods when the hunt is forbidden by the law. Small traces of Furadan has been found on the surface of fields, and also traces of dead animals consisting digested Furadan. The main problem according the use of this forbidden poison is his presence at open market places, where is possible to be found in large amounts. The poison is beeing used the way it is mixed with cow milk, for getting a suspension. That suspension is used to paint the seeds for planting crops, and after drying the seeds, landworkers found plantations and crops, thinking they protected cereals and vegetables from pests.

It is very hard to prove the usage of Furadan and its' presence in landworkers' ranches.

The same problems are present in hunting ground in Jazak, because those twoo hunting grounds share the same conditions for breeding the partridges, and there is no evident border between those twoo hunting grounds. The main cause of mortality of partridges in Jazak is usage of chemicals. The difference between protection the wildlife in Jazak and Mala Remeta lay in missing enough roads in Jazak hunting area. The Mala Remeta' hunting ground is divided on twoo sides, by the local road, that helps inspection to explore the hunting area in every occasion. In comparison to Jazak, whose hunting areas, formed from fields, are very far from the road, hunt inspectors find hardly to come and explore hunting areas at the right time, when dead partridges are evidented. In general, it is very easy to cover the traces of poisoning the birds and to remove the remains of dead partridges. 
In hunting ground in Stejanovci, according to report of hunters, the main problem in the past was using Furadan in protecting the crops. After the forbidding its' use, the population of partridges immediately grew.

The border between hunting grounds of Stejanovci-Mala Remeta revirs is known by increased number of abandoned dogs, but the hunters work on protecting the border and crops from dogs every year. The activities of that kind of wildlife protection are not accepted by non-government organizations, fighting for animal rights, so the functioning of the hunting associations is becoming complicated by, also, this very important factor. In the future, hunting associations should become more protected from conflicts with all parties involved in wildlife protection and protection of domestic animals, because the basic activity of hunting associations is breeding and the protection of animals in their natural habitats.

Deystoring of nests and eggs of grey partridges in Stejanovci is caused by increased usage of tractors. As the natural borders of todays' fields are covered with only small zones of weed vegetation, that does not give needed protection to partridges from the predators and also not enough space for making nests. Birds are making nests at places that are exposed to activity of tractors and heavy mechanization, so huge number of chicks, nests and eggs disappear from fields in Stejanovci in last three years.

Even in wider area of Vrdnik, the partridges are more protected by negative impacts on its' population, so the number of dead birds is especially huge according the presence of using diverse chemicals in protecting the crops. By the way, hunt productive area in Vrdnik is larger than all together areas of other three hunting grounds at $M t$. Fruška Gora, so the relative number of dead birds, even showing huge level of mortality caused by chemicals' usage, is not indicating alarming state of partridge' population, but it shows that, even the hunting area in Vrdnik is wider, there are not many birds poisoned by chemicals. Greatest problem would be usage of heavy mechanization in agriculture, that affect nests, females and chicks mostly.

In Sremska Rača, the biggest problem affecting the population of grey partridge is usage of heavy mechanization in agriculture, because the hunting association manage mostly the hunt productive fields in boundaries of hunting ground. Those fields are very large and this area of Vojvodina is, also, know by huge rate of modernization of agriculture mechanization. Tractor additions for planting the seeds are modern, developed and consisting more parts of composition, in comparison to older compositions of tractor additions.

After describing results given in tables and graphs in this study, and maintaining the key problems affecting the populations of grey partridge, we concluded that use of pesticides in agriculture caused basic problems in breeding grey partridge in hunting grounds at Mt. Fruška Gora, and usage of heavy mechanization in Agriculture in Sremksa Rača caused main problems in disappearing grey partridges from the fields. We can not identify the absolute number od poisoned birds in past by the pesticides, but we surely can say that protection measures of fields in agriculture represent the key for identifying the real cause of disappearing the grey partridge from their natural habitats. 
In Capital of the GREENPEACE' Report, printed in German language, originally named „Pestizide in der Landwirtschaft" („Pesticides in the Agriculture“), it is stated that the use of chemical-synthetic pesticides in agriculture began in the 1950's. There is also a classification of pesticides, which includes nine basic groups of pesticides used in agriculture, with the basic descriptions of the effects of certain pesticides: 1) Organohloropesticides (WILLET et al., 1998), 2) Organophosphate pesticides (skip OPP), 3) carbamates, according to MORAIS et al. (2012), include Aldicarb, Methiocarb, Primicarb, Maneb and Mancozeb, 4) Synthetic Pyrethroids, which according to KOUREAS et al. (2012) have a bad influence on the human endocrine system, 5) neonicotinoids, which form a new pesticide group of negative effects on the human nervous system, and have been in use since 1985 (KIMURAKURODA et al., 2012), 6) paraffins, 8) glyphosate (GUYTON et al., 2015) and 9) other types of pesticides of complex chemical structure.

In addition to negative effects of agriculture on grey partridge, it is evident that changing the shape and surface of frields also caused disappearing the grey partridge from fields. The key problem lay in missing enough hiding places, mating spots and making nests' adequate spots in fields.

It is important to imply the need of integral protection measures' control all over the breeding areas of grey partridge, because that species has became very sensitive to all other negative influences from the ecosystem. When its' natural habitat is damaged and affected by negative factors, grey partridge could also get attacked by parasites and infected by diseases.

In capital about the hair worm, MIKSCH et al., (1998-2004) give details of $E$. multilocularis worm female' segmented ovaries, with each of them consisting 300 eggs, from which number the $1 / 3$ is beeing layed in grey partridges' hair. That confirms the alarmance of grey partridges' parasite attacks' problem.

OPHOVEN, (2010) gives twoo different parasites always attacking the grey partridge: 1) The red worm and 2) The hair worms. According to MIKSCH et al., (19982004), the hair worms come in different colours when attacking the host, but also changing the colour when host getting sick.

So, if the future managers of hunting grounds would not implement the principle of integral protection of this species, grey partridge could be affected by the biological negative factors, even if the illegal hunt would disappear permanently and even if the chemicals used in agriculture become more ecologically acceptable. Every species is sensitive, not only to chemical and mechanical influences, but also to biological, so the future research of this problem can not stop on identifying only the chemical' and mechanical impacts on this game' survival.

Use of chemicals for protection of agricultural crops caused death of $10 \%$ of grey partridges in researched areas. Usage of chemicals is greater with growing needs of human population for bigger quantities of food and cereals. Destruction of nests and bird eggs of grey partridges is evidented in $12.5 \%$, and it is mostly caused by using a heavy mechanization in agriculture. New tractors are bigger and additions for planting seeds are wider and more complex, causing breaking eggs, killing chicks and hens. Even 
$5 \%$ of dead birds are killed in poach, that is very hard to prevent, because the system of monitoring the hunt activities is not full-time and hunting grounds generally do not have installed cameras for tracking the illegal hunt. The greatest problem in poisoning partridges is Furadan (5\%). This poison is very easy to find on open market places, and its' use is dangerous not only for wildlife, but also for humans. In general, the law should more protect hunting organizations from conflicts with local community and NGO's, because hunters are primarly protectors of the wildlife, that continiously work on improvement of breeding conditions for every game species. Supproting the hunting organizations, the wider area of hunting ground will gain more advantages, not only from aspect of game protection, but also protection of whole natural ecosystems.

\section{ACKNOWLEDGEMENT}

This paper was presented at International Symposium "People-Forest-Science", October 10-12, 2018, Sarajevo, Bosnia and Herzegovina.

\section{REFERENCES - Literatura}

AKTAR, W., SENGUPTA, D., CHOWDHURY, A., (2009): Impact of pesticides use in agriculture: their benefits and hazards. Interdisciplinary Toxicology. Mar; 2(1), p. $1-12$

GUYTON K., LOOMIS D., GROSSE Y., EL GHISSASSI F., BRENBRAHIM-TALLAA L., GUHA, N., SCOCCIANTI C., MATTOCK H., STRAIF K. (2015): Carcinogenicity of tetrachlorvinphos, parathion, malathion, diazinos, and glyphosate. Lancet Oncology. Also published online, March 20. DOI: http://doi.org/10.1016/514702045 Vol. 15, No. 70134. P. 8.

JOBLING, J.A. (2010): The Helm Dictionary of Scientific Bird Names. London: Christopher Helm. p. 297. ISBN 978-1-4081-2501-4.

KIMURA-KURODA J., KOMUTA., Y., HAYASHI, M., KAWANO, H. (2012): Nicotinelike effects of the neonicotinoid insecticides acetampirid and imidacleoprid on cellullar neurons from neonatal rats. PloS ONE 7. Vol. 324. P. 32.

KÖHLER, H.R. AND TRIEBSKORN, R. (2013): Wildlife exotoxicology of pesticides: can we track effects to the population level and beyond? Science, Vol. 341, P. 759765., published in Report of GREENPEACE, Capital: 3. „Pestizide und unsere Gesundheit". DIE SORGE WÄCHST. Mai 2015, Research Laboratories. P. 3, 6-8 DOI:

http://www,greenpeace.org/austria/Global/austria/dokumente/Reports/Bienen/Lan dwirtschaft_Pestizide-und-unsere-Gesundheit_2015.pdf

KOUREAS M., TSAKALOF, A., TSATSAKIS, A., HADJICHRITODOULOU, C. (2012): Systematic review of biomonitoring studies to determine the association between exposure to organophosphorus and pyrethroid insecticides and human health outcomes. Toxicology Letters Vol. 201. P. 155-168. 
Vlabılıty of the populatıons of Perdlx perdlx L. at Mt. Fruška Gora and Sremska Rača, Republic of Serbia

LONG, J. (1981): Introduced Birds of the World. Agricultural Protection Board of Western Australia. Terrey Hills, N.S.W. : Reed, p. 21-493.

MIKSCH, G., BANNERT, B., LUCIUS, R. (1998-2004). Parasiten Überlebenskünstlern auf der Spur, Parasiten, Leben und leben lassen. KOSMOS, first edition: 1998, Stuttgarter Beiträge zur Naturkunde, Serie C, 42, 102 S. () second edition: 2004, Staatliches Museum für Naturkunde Stuttgart und Franckh - Kosmos Verlags GmbH\&Co., Stuttgart. P. 4, 17, 33, 56. Alle Rechte vorbehalten ISBN: 3-44009991-1.

MORAIS S., DIAS, E., PEREIRA, M.L. (2012): Carbamates: human exposure and health effects. M. Jokanovic (ed.), The Impact of Pesticides. WY Academy Press Cheyenne. P. 21-38.

OPHOVEN, E. (2010). Wildtierkunde Biologie, Merkmale, Bejagung, Praxiswissen Jagd, empfolen von Wild und hund Deutsche Wildtier Stiftung, Einheimische in ihren Lebensräumen földern und erlebbar machen. KOSMOS. Capital: Federwild, p. 68. and Hühnervögel, p. 70-71.

WILLET, K.L., ULRICH, E.M., HITES, A. (1998): Differential toxicity and environmental fates of hexachlorocyclohexane isomers. Environmental Science and Technology. Vol. 32. P. 2197-2207.

\section{SAŽETAK}

Populacije Perdix perdix L. godinama su u padu na prirodnim staništima i područjima u koje je ta vrsta divljači introdukovana. Lovišta u podnožju Fruške Gore i u Sremskoj Rači u Republici Srbiji pružaju odlične uslove za njen uzgoj u prirodi. Pored podataka iz evidencija lovišta o brojnom stanju, relevantan uvid u brojno stanje $P$. perdix na terenu omogućava direktno praćenje stanja populacija u lovnim atarima lovačkih društava. Na opadanje njene brojnosti najviše utiče primjena hemijskih sredstava za zaštitu poljoprivrednih usjeva (10\%), uništavanje gnijezda i jaja (12,5\%), nepridržavanje odredaba zaštite $P$. perdix kojima se zabranjuje lov dok se njena populacija ne uveća $(5 \%)$, te upotreba otrova na poljoprivrednim usjevima, poput zabranjenog otrova Furadana (5\%). Iako nisu dobijeni značajniji rezultati o uticaju predatora i napuštenih životinja na smanjenje brojnosti $P$. perdix, postoji opravdana zabrinutost lovačkih društava u pogledu pronalaska ekološki i biološki održivih rješenja namnoženja predatora na pernatu divljač i posebno napuštenih pasa. Rezultati istraživanja su dobijeni metodom direktnog utvrđivanja brojnog stanja $P$. perdix na terenu, u lovnim atarima L.D. „Fazan Mala Remeta“, L.D. „Fazan“ Jazak, L.D. „Stejanovci“ Stejanovci, L.D. „Zec“ Vrdnik i L.D. „Srndać“ Sremska Rača. Dobijeni rezultati direktno upućuju na potrebu uvođenja principa integralne zaštite $P$. perdix, koji podrazumijeva kontrolu provođenja mjera zaštite poljoprivrednih usjeva i provođenja mjera zaštite $P$. perdix tokom organizovanja lovova u lovištima na druge vrste divljači.

Corresponding autor: Selma Vejzagić, MA Forestry, Faculty of Forestry, University of Sarajevo, Zagrebačka 20, 71000 Sarajevo, Bosnia and Herzegovina; e-mail address: zastitasuma.bih@gmail.com 